\title{
INTELLIGENT PREDICTING SYSTEM FOR MODELING OF FLEXURALLY - STRENGTHENED REINFORCED CONCRETE BEAMS WITH CFRP LAMINATES
}

\author{
IBRAHIM M. METWALLY
}

In the last years, a great number of experimental tests have been performed to determine the ultimate strength of reinforced concrete (RC) beams retrofitted in flexure by means of externally bonded carbon fiber-reinforced polymers (CFRP). Most of design proposals for flexural strengthening are based on a regression analysis from experimental data corresponding to specific configurations which makes it very difficult to capture the real interrelation among the involved parameters. To avoid this, an intelligent predicting system such as artificial neural network (ANN) has been developed to predict the flexural capacity of concrete beams reinforced with this method. An artificial neural network model was developed using past experimental data on flexural failure of RC beams strengthened by CFRP laminates. Fourteen input parameters cover the CFRP properties, beam geometrical properties and reinforcement properties; the corresponding output is the ultimate load capacity. The proposed ANN model considers the effect of these parameters which are not generally account together in the current existing design codes with the purpose of reaching more reliable designs. This paper presents a short review of the well-known American building code provisions (ACI 440.2R-08) for the flexural strengthening of RC beams using FRP laminates. The accuracy of the code in predicting the flexural capacity of strengthened beams was also examined with comparable way by using same test data. The study shows that the ANN model gives reasonable predictions of the ultimate flexural strength of the strengthened RC beams. Moreover, the study concludes that the ANN model predicts the flexural strength of FRPstrengthened beams better than the design formulas provided by ACI 440 .

Keywords: CFRP laminates, RC beam, flexural capacity, neural networks, ACI 440

\section{Introduction}

The use of fiber reinforced polymer (FRP) sheets as externally bonded reinforcement is nowadays widely recognized as an efficient method for strengthening and upgrading reinforced concrete RC members. In particular, the flexural strength of a reinforced concrete beam can be extensively increased by application of carbon, glass and aramid FRP plates/sheets adhesively bonded to the tension face of the beam (Bank, 2006). In general, external reinforcement by FRP sheets is used for flexural strengthening, improving ductility, and shear strengthening. Over past few years, external strengthening using FRP composites gained popularity over steel

Concrete Structures Research Inst., Housing \& Building Research Centre, P. O. Box 1770 Cairo, Egypt, e-mail: dr_ibrahimmetwally@yahoo.com 
because of several reasons including material cost, lightweight feature, corrosion free and ease of application. At the same time, widespread experimental, numerical and analytical research has been carried out to understand and model the structural behavior of FRP strengthened reinforced concrete beams. Many studies have been done for recognizing and understanding the failure modes that reinforced concrete beams retrofitted with FRP. There are three main categories of failure in concrete structures retrofitted with FRP that have been observed experimentally (Coronado and Lopez, 2006; Ebead and Marzouk, 2005; Lundquist et al., 2005). The first and second type consist of failure modes where the composite action between concrete and FRP is maintained. Typically, in the first failure mode, the steel reinforcement yields, followed by rupture of CFRP as shown in Figure l (a). In the second type, there is failure in the concrete. This type occurs either due to crushing of concrete before or after yielding of tensile steel without any damage to the FRP laminate (Fig. l (b)), or due to an inclined shear crack at the end of the plate (Fig. 1(c)). In the third type, the failure modes involving loss of composite action are included. The most recognized failure modes within this group are debonding modes. In such a case, the external reinforcement plates no longer contribute to the beam strength, leading to a brittle failure if no stress redistribution from the laminate to the interior steel reinforcement occurs. Figures $1(\mathrm{~d})-(\mathrm{g})$ show failure modes of the third type for RC beams retrofitted with FRP. In Figure 1(d), the failure starts at the end of the plate

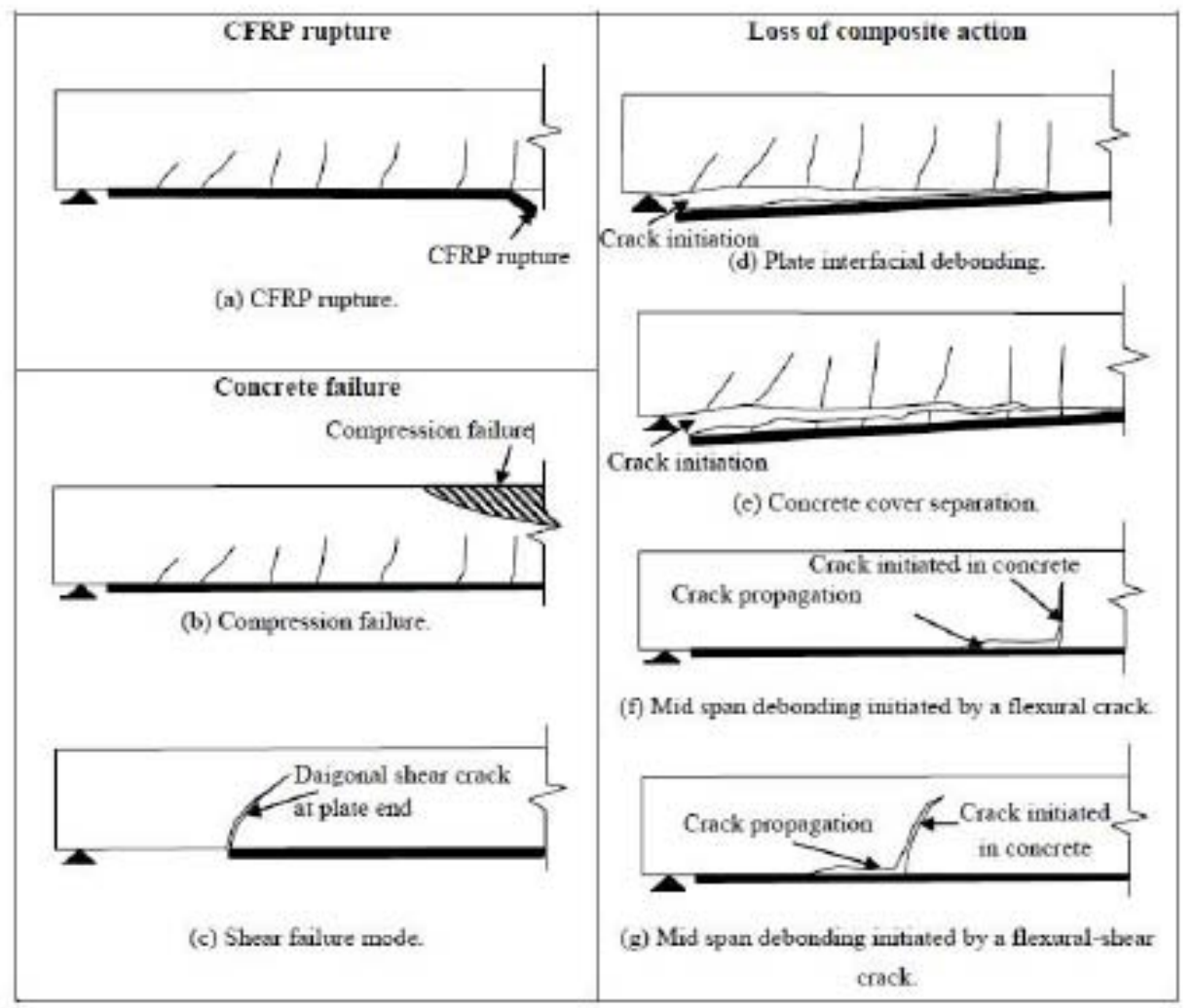

Figure 1. Failure modes in beam retrofitted with FRP sheets in flexure [4] 
due to the stress concentration and ends up with de-bonding propagation inwards. Stresses at this location are essentially shear stress but due to smal1 but non-zero bending stiffness of the laminate, normal stress can arise. In Figure 1 (e), the entire concrete cover is separated. This failure mode usually results from the formation of a crack at or near the end of the plate, due to the interfacial shear and normal stress concentrations. Once a crack occurs in the concrete near the plate end, the crack will propagate to the level of tensile reinforcement and extend horizontally along the bottom of the tension steel reinforcement. With increasing external load, the horizontal crack may propagate to cause the concrete cover to separate with the FRP plate. In Figure 1 (f) and (g), the failure is caused by crack propagation in the concrete parallel to the bonded plate and adjacent to the adhesive to concrete interface, starting from the critically stressed portions towards one of the ends of the plate. It is believed to be the result of high interfacial shear and normal stresses concentrated at a crack along the beam. Also mid span de-bonding may take concrete cover with it.

This paper proposes a new approach to the problem, using an empirical model developed from observations of the actual performance of laboratory beams. Specifically, a neural network approach is proposed due to its proven abi1ity to solve problems of this type. That is, problems requiring the rapid generation of solutions, the accurate modeling of functions that are non-linear, and comprise many poorly defined independent variables. The objective was to determine the viability of using this approach to obtain accurate predictions of the maximum strength of externally CFRP-strengthened RC beams. As an added advantage, the neural network approach was expected to make predictions of beam performance within a fraction of a second. This, in turn, would make it possible to evaluate a very large number of alternative external reinforcement configurations, and thus determine a more optimal design solution. The success of experimental studies produced growing demand for analytical investigations since predicting the ultimate flexural strength of the strengthened RC structures is crucial. Therefore, several proposed analytical formulations have been developed to guide the design, detailing and installation of FRP based systems (ACCI Committee 440, 2008; Fib Bulletin 14, 2001; Canadian Standards Association, 2002; CNR, 2005; CIDAR, 2006). The developed analytical equations estimated the contribution of FRP reinforcements within certain limits but not accurately in some cases. The assumptions that were made while designating the behavior of the strengthened specimen did not resemble to actual behavior due to some special situations and that cause the calculated results to be different from the obtained flexural capacity. There are several parameters that cause differences between the calculated and the obtained flexural capacity. For example, some design guidelines and codes ignore the influence of the length of FRP sheet, concrete compressive strength, and concrete cover in tension zone on prediction of ultimate flexural capacity. These are the major assumptions that cause divergence towards the experimental results, Since the ultimate flexural behavior of strengthened RC beam is affected by many factors and parameters, artificial neural network (ANN) method can be used as an effective tool to predict the ultimate flexural behavior of strengthened RC beams (Guang and Zong, 2000; Sanad and Saka, 2001; Jamal et al., 2007; Ghaboussi et al., 1991; Hajela and Berke, 1991). The proposed ANN model considers the effect of various parameters (Table 1) which is not generally account together in existing design codes. ANN model contains data for both application schemes. Eighty three (83) experimental data of CFRP-strengthened RC beams were collected from literature. As it is aimed to suggest a practical ANN model, the mechanical properties of strengthening material and mechanical and dimensional properties of beams are selected as inputs (Table 1 ). The predicted ANN results are primarily compared 
with experimental CFRP contributions of strengthened beams and then with the predicted results of theoretical guideline equation by American guidelines ACI 440 [1]. It was chosen among all current design codes, because it attained the best prediction of flexural capacity of FRP-strengthened RC beams as reported by Al-Zaid et al. (2012). Performed analysis showed that the neural network model is more accurate than the ACI 440 guideline equation with respect to the experimental results and it can be applied satisfactorily within the range of parameters covered in this study.

Table 1. Range of input parameters and output variables

\begin{tabular}{|c|c|c|c|c|}
\hline \multirow{2}{*}{ Input no. } & Parameter & Symbol & Minimum & Maximum \\
\hline & \multicolumn{4}{|c|}{ Inputs } \\
\hline 1 & $\begin{array}{l}\text { Concrete cylinder comp. strength, } \\
\qquad \mathrm{MPa}\end{array}$ & $f_{\mathrm{c}}^{\prime}$ & 18 & 55.2 \\
\hline 2 & Width of beam, mm & $b$ & 100 & 500 \\
\hline 3 & Effective depth, mm & $d$ & 50.8 & 419 \\
\hline 4 & Effective span, $\mathrm{mm}$ & $l$ & 1400 & 5000 \\
\hline 5 & Area of tension reinforcement, $\mathrm{mm}^{2}$ & $A_{\mathrm{s}}$ & 71 & 2413 \\
\hline 6 & Area of comp. reinforcement, $\mathrm{mm}^{2}$ & $A_{\mathrm{s}}^{\prime}$ & 28 & 1609 \\
\hline 7 & Yield strength of steel rfts, MPa & $f_{\mathrm{y}}$ & 335 & 590 \\
\hline 8 & $\begin{array}{l}\text { Modulus of elasticity of of steel rfts, } \\
\qquad \mathrm{GPa}\end{array}$ & $E_{\mathrm{s}}$ & 165 & 201 \\
\hline 9 & Concrete cover in tension side, mm & $\mathrm{COV}$ & 15 & 55 \\
\hline 10 & No. of CFRP layers & $n_{\mathrm{f}}$ & 1 & 4 \\
\hline 11 & $\begin{array}{l}\text { Modulus of elasticity of CFRP sheet, } \\
\text { GPa }\end{array}$ & $E_{\mathrm{f}}$ & 11 & 240 \\
\hline 12 & Width of CFRP sheet, mm & $b_{\mathrm{f}}$ & 25 & 480 \\
\hline 13 & Thickness of CFRP sheets, mm & $t_{\mathrm{f}}$ & 0.11 & 6 \\
\hline 14 & Length of CFRP sheet, mm & $l_{\mathrm{f}}$ & 1200 & 4800 \\
\hline Output no. & \multicolumn{4}{|c|}{ Output } \\
\hline 1 & Ultimate flexural load, $\mathrm{kN}$ & $P_{\mathrm{u}}$ & 16.1 & 669.3 \\
\hline
\end{tabular}

\section{Experimental technique and data}

An extensive literature review has been carried out and eighty three (83) RC beams strengthened in flexure with CFRP laminates were collected from the published literature. These test results are used to provide the experimental data for ANN. All tested beams are simply supported and subjected to two point loads acting symmetrically with respect to the centerline of the span as shown in Figure 2. This case provides a larger amount of data, which is 
essential for better training of a network. During the collection of the data, specimens that do not have flexural failures have been excluded from the training set. The selected specimens covered all modes of failure of flexurally - strengthened RC beams with CFRP laminates as mentioned above. The basic parameters that control the ultimate load of beams, based on previous research works are listed in Table 1 . The experimental data include 83 beam results, which are taken from the tests carried out by references $[2-5,7,9,10,13,14,18,19,21,24$, 28, 30, 32 - 36 and 38] as shown in Appendix A. The data are rearranged in such a way that 14 basic parameters are listed as input values, and the ultimate load is included as the corresponding output targets (Table 1). There is no single design code that considers all these parameters.
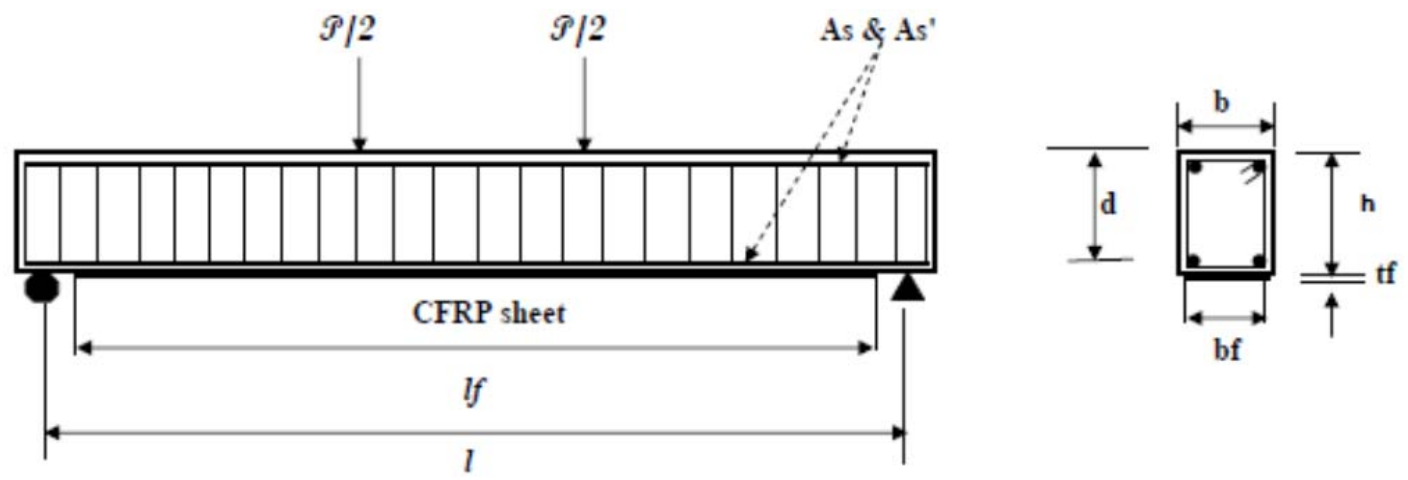

Figure 2. Typical FRP-strengthened RC beam

\section{Analytical study}

\subsection{Neural Network Model of CFRP-Strengthened Beams}

An artificial neural network (ANN) is a simplified mathematical model or computational model that tries to simulate the structure and/or functional aspects of biological neural networks for engineering problems. It contains an interconnected group of artificial neurons and processes information using a connectionist approach to computation. In most cases, the ANN is an adaptive system that changes its structure based on external or internal information that flows through the network during the learning phase and can be used as a prediction tool for cases where the output solution is not available. Modern neural networks are non-linear statistical data modeling tools. ANN contains three main sections which are classified as, input layer, hidden (inner) layer, and the output layer. Input parameters are presented in the input layer and the solution of the problem is evaluated with the output layer. In between these layers, hidden layer is placed and provides help to the network in the learning process. The number of neurons of the input and output layers are determined in order to represent the characteristic of the existing problem accurately. Hidden layers can be formed with one or more layers and the number of neurons in the hidden layer is determined by the users. The number of the neurons in the input layer is equal to the number of the independent variables in the experiment as shown in Table l. The number of the hidden layers and the number of 
the neurons in each layer is chosen to provide a minimum value for the error between the measured output and the network's output while maintaining the ability of the network to generalize. In the current research, Feed-forward back-propagation neural networks (FBNNs) were applied for prediction the capacity of strengthened beams with one input layer (it contains 14 independent variables (Table l) that may affect the flexural capacity), one hidden layer have 20 neurons, and one output layer was designed to predict the flexural load capacity. The TRAINLM training function available in MATLAB Neural Toolbox [31] was used to train the network using the LERNGDM adaption learning function. The input data was divided into three sets. The first set consists of $70 \%$ of the data is used to train the network. The second and third sets, each consists of $15 \%$ of the data are used to validate and test the generalization ability of the network, respectively. Several architectures were tried and the one that gave the least error was chosen (Fig. 3). The selection of optimal configuration of ANN is the key point to achieve successful results from the suggested ANN model. Therefore, the mechanical properties of strengthening material and mechanical and dimensional properties of experimental beams are selected as inputs. In the literature, the strengthened specimens have concrete strength is generally above $20 \mathrm{MPa}$. In addition, some guidelines (Chajes et al., 1994) do not propose to use FRP strengthening technique (due to the bond problems) to the structures with compressive strength below $17 \mathrm{MPa}$. However, the concrete strength of buildings that require retrofitting is generally lower than the pre mentioned value. In this study, the structures that have low concrete compressive strength are also accounted in the proposed ANN model in order to achieve the aspects of strengthening philosophy. Therefore, experimental data that will direct ANN model to evaluate such structures was especially collected from literature. The neural network model is built by considering these approaches and it contains fourteen input nodes (Table 1). The optimum network is selected based on minimum error and maximum correlation coefficient between data. The properties of the selected network are shown in Table 2.

Table 2. The Network Properties

\begin{tabular}{|c|c|c|c|}
\hline No. & Parameter & Property & \multirow{2}{*}{$\mathrm{R}$} \\
\cline { 1 - 3 } 1 & Network function & $\begin{array}{c}\text { Feed-forward back- } \\
\text { propagation }\end{array}$ & \\
\hline 2 & Network architecture & $14-20-1$ & \\
\hline 3 & The number of training data & 59 & 0.99 \\
\hline 4 & The number of verifying data & 12 & 0.99 \\
\hline 5 & The number of testing data & 12 & 0.96 \\
\hline 6 & No. of all data & 83 & 0.99 \\
\hline
\end{tabular}

In this section, an experimental database (consists of 83 RC beams strengthened with CFRP sheets in flexure) is used to investigate the accuracy of ACI 440, and train and test the ANN model in the prediction of the flexural load of RC beams. The results of the ANN model are compared with ACI 440 empirical code, based on calculating the mean (M), standard deviation (STD), coefficient of variation (COV), and variation (VAR). Also, the $\mathrm{R}^{2}$ of the linear regression line for the predicted values by both ANN model and ACI 440 code are determined. 


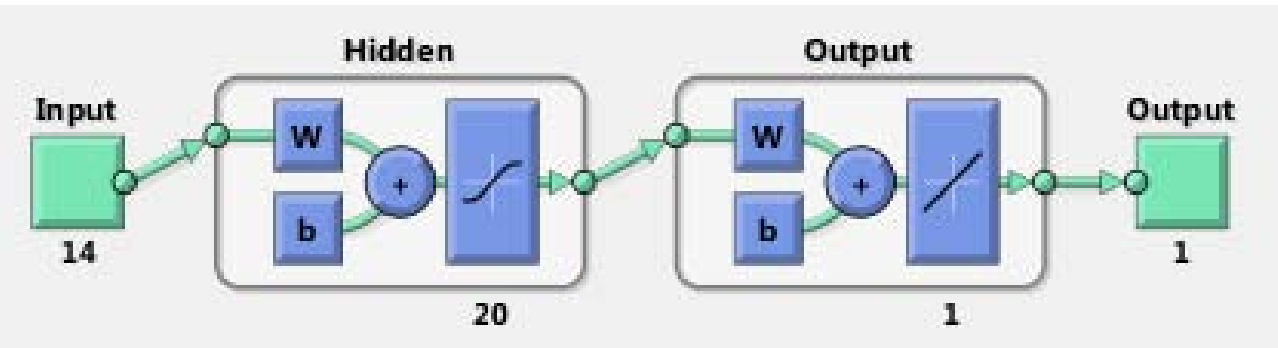

Figure 3. Artificial Neural Network Structure
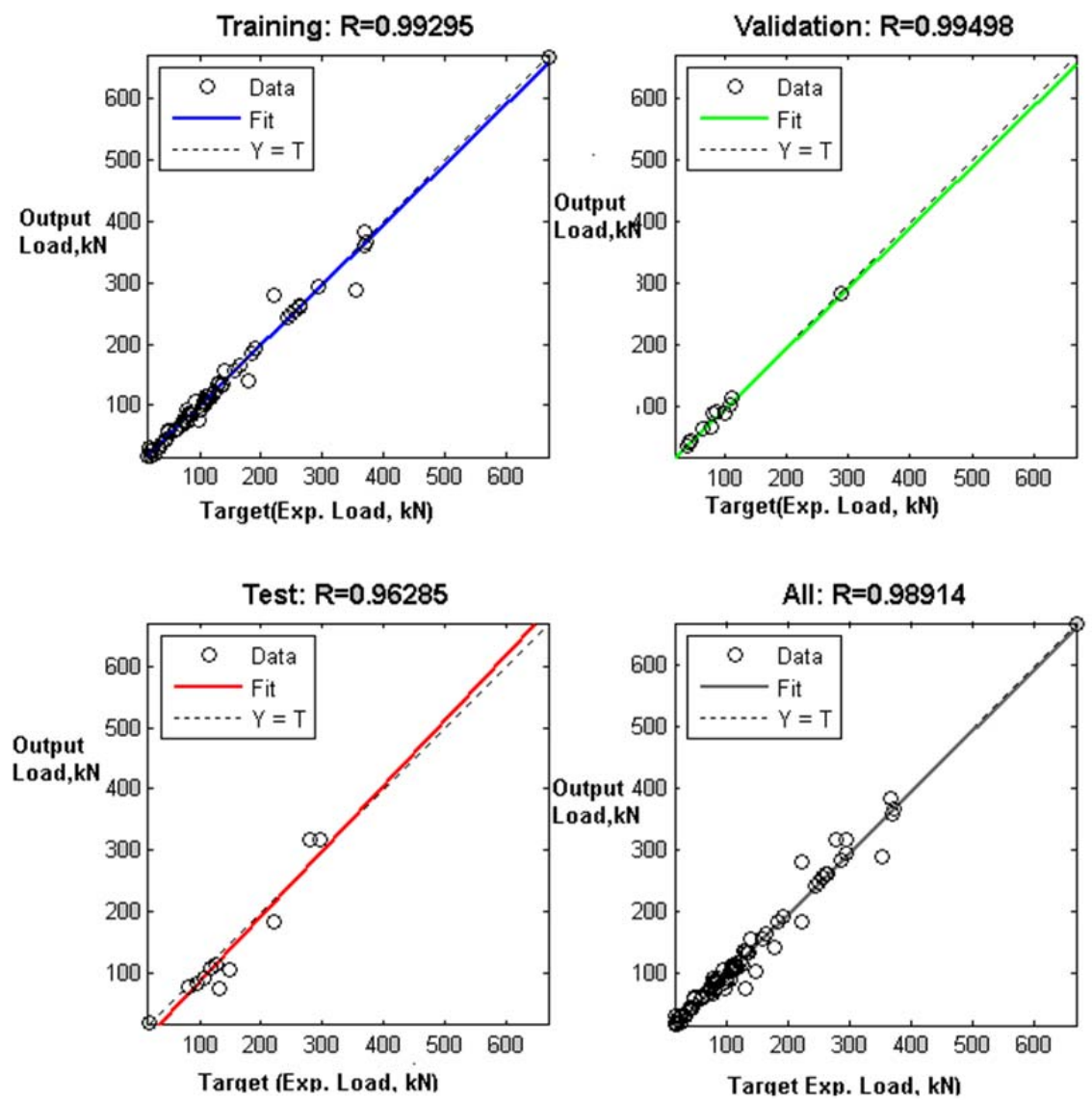

Figure 4. Regression analysis for training, validation, testing, and whole data 
Figure 4 shows the relationship between the experimental data and the training, validation and testing sets. It can be shown that the relationship between the complete set of the experimental data and the data predicted by the neural network is excellent.

To show the efficiency of the proposed ANN model, the experimental database are used and the flexural load of CFRP-strengthened RC beams is calculated using ACI 440 formula and ANN model. Also, to evaluate the performance and accuracy of the ACI 440 and ANN, values of the flexural capacity from ACI 440 design code and ANN are compared with measured experimental data. Comparisons between observed (experimental) and predicted flexural load are shown in Figure 5. It can be seen that the predicted loads by ACI 440 are more scattered from the experimental ones compared to ANN predictions.

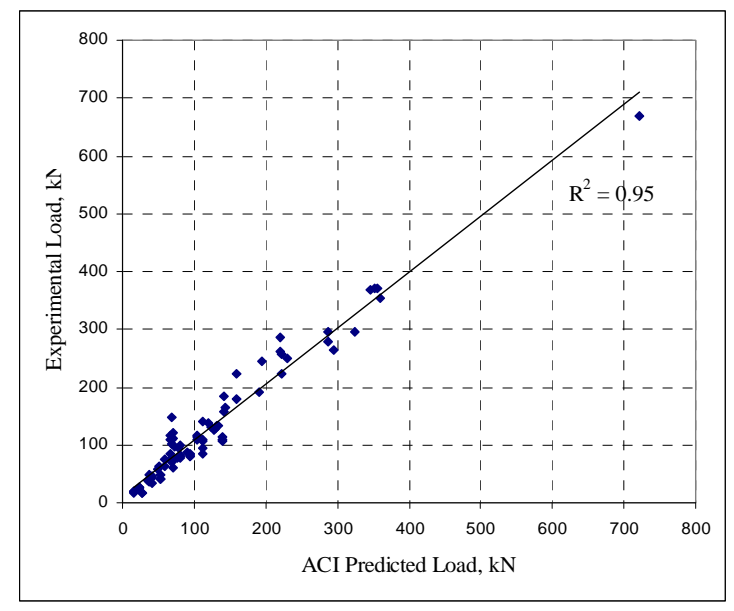

a) ACI 440 Formula

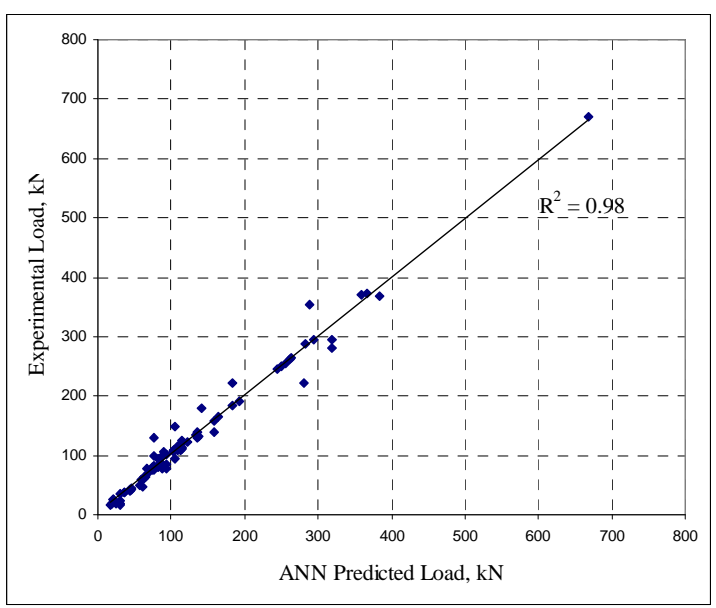

b) ANN Model

Figure 5. Comparison between experimental and predicted flexural capacities 
To show the superiority of proposed ANN model, the mean (M), standard deviation (STD), coefficient of variation (COV), variation (VAR), and $\mathrm{R}^{2}$ values for ANN model and ACI 440 code are presented in Appendix A and Figure 5. Comparison of the results indicates that the ANN model has satisfactory values of R-square and $\mathrm{M}$ (close to one) and a lower value of STD, $\mathrm{COV}$ and VAR, so that its performance is more accurate. Also, the ANN model performs a much better prediction, compared with ACI 440 empirical code.

Figure 5 shows a linear regression between the experimental and the neural loads. The agreement is excellent as attested to by the $\mathrm{R}^{2}$-value (0.98) of the regression analysis and descriptive statistics (Mean $=1.01, \mathrm{STD}=0.15, \mathrm{COV}=15.12$, $\mathrm{VAR}=0.02)$ it means that the prediction by neural networks have a smallest coefficient of variation, smallest scatter and better confidence intervals compared with ACI 440 ( Mean $=1.09$, STD $=0.25$, $\mathrm{COV}=22.68$, VAR $=0.06)$ as reported in Appendix A. ACI 440 produced nearly close predictions to the experimental results. However, at almost every step they underestimated the experimental results and this shows that their predictions are always on the safe side because of the safety factors that were used while calculation.

\subsection{Influencing of Input Parameters}

Because the weight of input parameters in the network cannot be easily understood in the form of a numeric matrix, they may be transformed into coding values in the form of a percentage by dividing the weights by the sum for all the input parameters, which gives the relative importance for each input parameter to output parameter. The relative importance for various input parameters are shown in Figure 6. As the figure indicates, the major important and influencing parameters are the beam depth (18.8 \%) and length of CFRP sheet (16.1) while the most of other input parameters has insignificant importance on the predicting of ultimate load

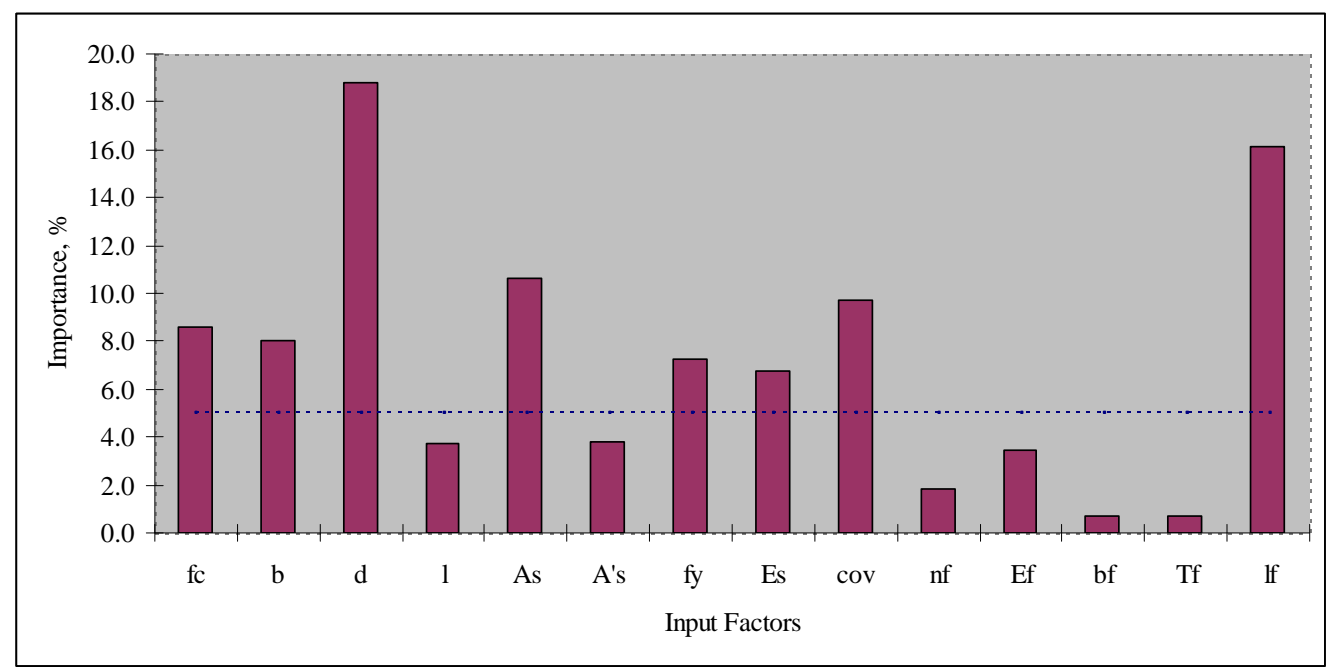

Figure 6. Relative importance of input parameter for ANN model 

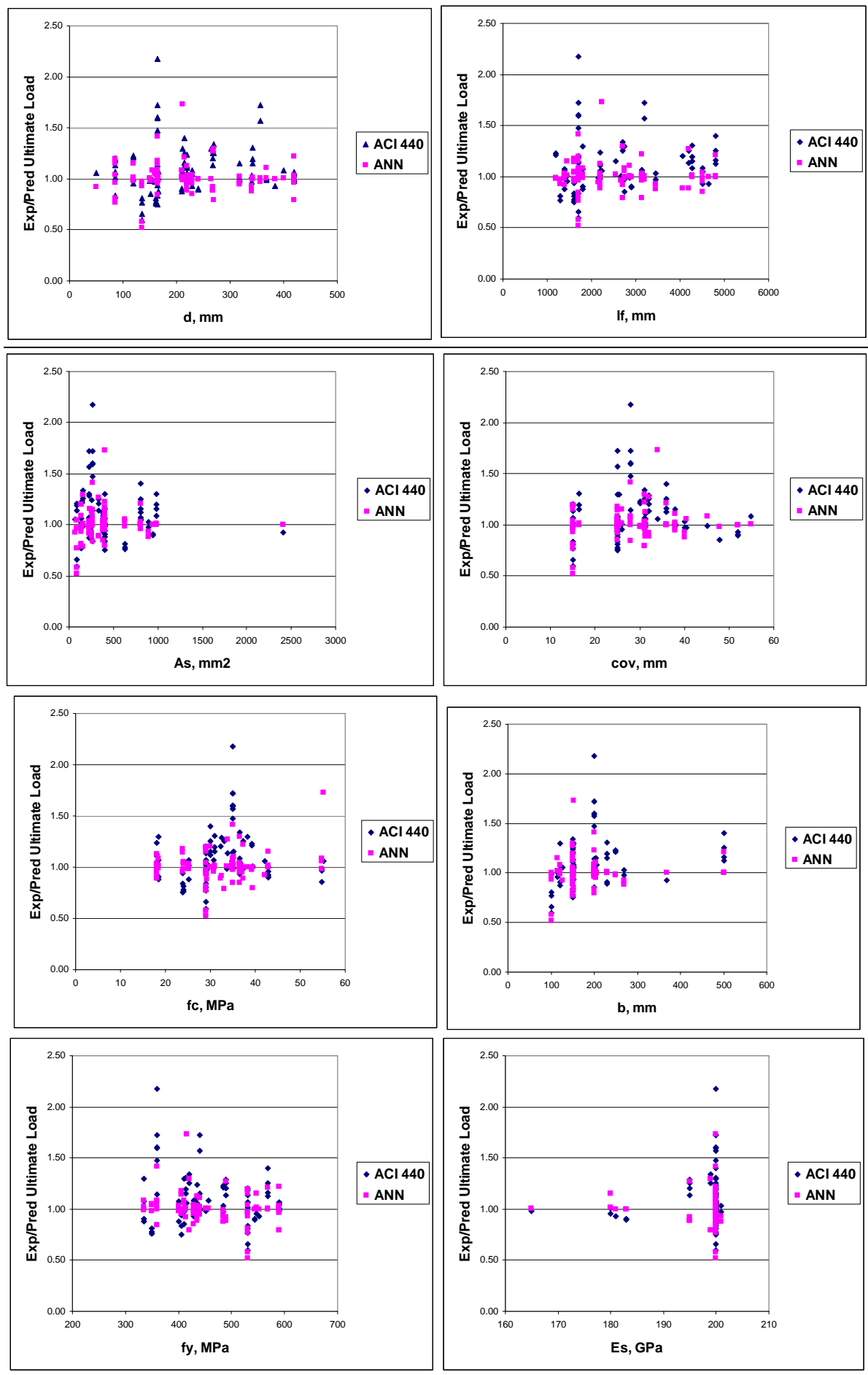

Figure 7. Experimental to predicted ultimate flexural loads of CFRP-strengthened beams versus $d, l_{\mathrm{f}}, A_{\mathrm{s}}, \operatorname{cov}, f_{\mathrm{c}}, b, f_{\mathrm{y}}$, and $E_{\mathrm{s}}$ respectively. 
(10.6 \% $-0.7 \%)$. Beside the beam depth and length of CFRP sheet, six parameters were select from the residual twelve parameters, (which have importance more than $5 \%$ which is considered as the min limit as reported by Yousif and Al-Jurmaa (2010)), these are $\left(A_{\mathrm{s}}, \operatorname{cov}, f_{\mathrm{c}}\right.$, $b, f_{\mathrm{y}}$, and $\left.E_{\mathrm{s}}\right)$.

Figure 7 also present the experimental-to-calculated flexural load versus $d, l_{\mathrm{f}}, A_{\mathrm{s}}, \operatorname{cov}, f_{\mathrm{c}}, b, f_{\mathrm{y}}$, and $E_{\mathrm{s}}$, from this figure, it is evident that the level of accuracy of the ultimate flexural load predicted by the ANN model seems to be consistent with the varying the various parameters. The proposed model has been compared to the current design guidelines provided by ACI 440 . More accurate and consistent predictions have been obtained using the model produced by ANN.

\section{CONCLUSIONS}

The following conclusions can be drawn based on the performed analyses and comparisons reported in this paper:

1. In this study, a Feed-forward back-propagation neural network with fourteen input neuron, twenty hidden neurons and one output neuron was developed to introduce a reliable flexural design of CFRP-strengthened RC beams with high accuracy. Results show that the ANN model provided a better prediction of flexural load than the ACI 440 model and is more accurate. In addition, the predictions of ANN model were distributed around experimental results, while ACI 440 was more scattered from experimental results, indicating that they predominately under-estimate the flexural capacities.

2. The proposed ANN model provides the most accurate results in calculating the ultimate flexural load. It considers the effect of various 14 parameters which is not generally account together in the current existing design codes.

3. The effective beam depth and length of CFRP sheet are the major important and influencing parameters that affecting the prediction of the ultimate load capacity of RC beams strengthened with CFRP sheet.

4. Some guidelines do not recommend the use of FRP strengthening technique (due to the bond problems) to the structures with compressive strength below $17 \mathrm{MPa}$. However, the concrete strength of buildings that require retrofitting is generally lower than the pre mentioned value. Therefore, an ANN model is developed that is addressing the need for retrofitting structures with low concrete compressive strength in this study. Accordingly, obtained results showed that ANN model can successfully predict the FRP contribution for structures with low concrete compressive strength within acceptable limits.

\section{REFERENCES}

[1] ACI Committee 440.2R-08 (2008), Guide for the Design and Construction of externally bonded FRP systems for strengthening concrete structures, American Concrete Institute Committee.

[2] Alagusundaramoorthy, P., Harik, I. and Choo, C. (2002), Flexural Behaviour of RIC Beams Strengthened with CFRP sheets or Fabric, Reseach Report No. KTC-02-13/SPR200-99-1 F, Kentucky Transportion Center, University of Kentucky, 35.

[3] Ai-Hui, Z., Wei-Liang, J. and Gui-Bing L. (2006), "Behavior of Preloaded RC Beams Strengthened with CFRP Laminates”, Journal of Zhejiang University 7, 436-444. 
[4] Al-Negheimish, A.I., Shuraim, A. B., Al-Zaid, R.Z, Al-Huzaimy, A. M. and El-Sayed, A. K. (2011), Innovative procedure for strengthening wide shallow beam floor system using CFRP reinforcement. 2nd year progress report, submitted to center of excellence for research in engineering materials (CEREM), King Saudi University.

[5] AI-Zaid, R. Z., Shuraim, A. B., El-Sayed, A. K., Al-Negheimish, A. I. and Al-Huzaimy, A. M. (2010), "Flexural strengthening of shallow reinforced concrete beams using CFRP plates”, 2nd international structural specialty conference (on CD-R), CSCE, Winnipeq, Canada, 9-12.

[6] Al-Zaid, R., Al-Negheirnish, A., Al-Saawani, M. and El-Sayed, A. (2012), “Analytical study on RC beams strengthened for flexure with externally bonded FRP reinforcement”, Composites: Part B, 43, 129-141.

[7] Aram, M. R., Czaderski, C. and Motavalli, M. (2008), “Debonding failure modes of flexural FRP strengthened RC beams”, Compos Part B 39, 826-41.

[8] Bank, L. C. (2006), Composites for Construction: Structural Design with FRP Materials, John Wiley and Sons.

[9] Bonacci, J. F. and Maalej, M. (2000), "Externally bonded fiber-reinforced polymer for rehabilitation of corrosion damaged concrete beams”, ACI Struct J 97, 703-711.

[10] Brea, S. F., Bramblett, R. M., Wood, S. L. and Kreger, M. E. (2003), “Increasing flexural capacity of reinforced concrete beams using carbon fiber-reinforced polymer composites”, ACI Struct J 100, 2003 36-46.

[11] Canadian Standards Association (2002) Design and construction of Building Components with Fiber-Reinforced Polymers, CSA-S806-02, Rexdale, Ontario, Canada.

[12] Ceroni, P., Prota, A. and Pecce, M. (2002), “Analysis of the Behavior of Concrete Beamswith FRP Laminates”, Structural Composites for Infrastructure Applications Conference, Aswan, Egypt.

[13] Ceroni, F. (2010), “Experimental performances of RC beams strengthened with FRP materials”, Constr Build Mater 24, 1547-59.

[14] Chajes, M. J., Thomson, T. A. and Januszka, T. F. (1994), "Finch WW. Flexural strengthening of concrete beams using externally bonded composite materials”, Constr Build Mater 8, 191-201.

[15] CIDAR (2006), Design guideline for RC structures retrofitted with FRP and metal plates: beams and slabs. Draft 3 - submitted to Standards Australia, The University of Adelaide.

[16] CNR (2005), Guidelines for Design, Execution and Control of Strengthening Interventions by Means of Fibre-reinforced Composites, Bulletin DT 200/2004, CNR, Roma, Italy (English version).

[17] Coronado, C. A. and Lopez, M. M. (2006), "Sensitivity analysis of reinforced concrete beams strengthened with FRP laminates”, Cement and Concrete Composites 28, 102-114. 
[18] Dai, J ., Ueda, T., S ato, Y . and Ito, T. (2005), “Flexural Strengthening of RC Beams using Externa1Jy Bonded FRP Sheets Through Flexible Adhesive Bonding”, Proceedings of the Internationa1 Symposium on Bond behavior of FRP in Structures, International Institute for FRP in Construction, 205-214.

[19] Dong, Y., Zhao, M. and Ansari, F. (2002), "Failure characteristics of reinforced concrete beams repaired with CFRP composites”, Proceedings of the third international conference on composites in infrastructure (ICCI'02). Berlin: Springer, 51-65

[20] Ebead, U. A. and Marzouk, H. (2005), “Tension - stiffening model for FRP strengthened RC concrete two-way slab”, Materials and Structures 38, 193-200.

[21] Esfahani, M., Kianoush, M. and Tajari, A. (2007), "Flexural behavior of reinforced concrete beams strengthened by CFRP sheets”, Engineering Structures 29, 2428-2444.

[22] Fib (2001), Bulletin 14, “Externally bonded FRP reinforcement for RC structures”, Technical Report, Task Group 9.3 FRP (fiber reinforced polymer) reinforcement for concrete structures.

[23] Ghaboussi, J., Garret Jr., J. H. and Wu, X. (1991), "Knowledge-based modeling of material behavior with neural networks”, J Eng Mech, ASCE 117, 132-53.

[24] Grace, N. F., Abdel-Sayed, G. and Ragheb, W. F. (2002), "Strengthening of concrete beams using innovative ductile fiber-reinforced polymer fabric”, ACI Struct J 99, 692-700.

[25] Guang, N. H. and Zong, W. J. (2000), "Prediction of compressive strength of concrete by neural networks”, Cement and Concrete Research 30, 1245-1250.

[26] Hajela, P. and Berke, L. (1991), "Neuro-biological computational models in structural analysis and design”, Comp Struct 41, 657-67.

[27] Jamal, A., Abdalla, A., Elsanosi, A. and Abdelwahab, A. (2007), "Modeling and simulation of shear resistance of RIC beams using artificial neural network", J Franklin Inst 344, 741-56.

[28] Kotynia, R. (2005), “Debonding failures of RC beams strengthened with externally bonded strips”, Proceedings of the international symposium on bond behavior of FRP in structures (BBFS 2005), Chen, Teng, editors, International Institute for FRF in Construction.

[29] Lundquist, J., Nordin, H., Taljsten, B. and Olafsson, T. (2005), “Numerical analyis of concrete beams sterengthened with CFRP - A Study of anchorage lengths”, FRP in Construction, Proceeding of The International Symposium of Bond Behaviour of FRP in Structures, 247-254.

[30] Maalej, M. and Leong, K. S. (2005), "Effect of beam. size and FRP thickness on interfacial shear stress concentration and failure mode of FRP-strengthened beams", Compos Sci Technol 65, 1148-1158.

[31] MathWorks Inc. (2012), MatLab the language of technical computing. Natick, MA, USA: MathWorks Inc; Version 2012a. 
[32] Matthys, S. (2000), Structural behavior and design of concrete beams strengthened with externally bonded FRP reinforcement. PhD thesis. Ghent University.

[33] Neagoe, C. (2011), Concrete Beams Reinforced with CFRP Laminates, M.Sc. Thesis, Universitat Politecnica de Catalunya.

[34] Reeve, B. Z. (2005), Effect of adhesive stiffness and CFRP geometry on the behavior of externally bonded CFRP retrofit measures subject to monotonic loads, MSc. Thesis, University of Pittsburgh.

[35] Ross, C. A., Jerome, D. M., Tedesco, J. W. and Hughes, M. L. (1999), "Strengthening of reinforced concrete beams with externally bonded composite laminates”, ACI Struct J 96, 212-221.

[36] Saadatmanesh, H. and Ehsani, M. R. (1991), "RC beams strengthened with GFRP plates. I: experimental study”, J Struct Eng 117, 3417-3433.

[37] Sanad, A. and Saka, M. P. (2001), "Prediction of ultimate shear strength of reinforced concrete deep beams using neural networks”, J Struct Eng, ASCE, 127, 818-828.

[38] Shin, Y. S. and Lee, C. (2003), "Flexural behavior of reinforced concrete beams strengthenedwith carbon fiber-reinforced polymer laminates at different levels of sustaining load”, ACI Struct J 100, 231-239.

[39] Yousif, S. and Al-Jurmaa, M. (2010), "Modeling of ultimate load for R.C. beams strengthened with Carbon FRP using artificial neural networks", Al-Rafidain Engineering 18, 28-41. 


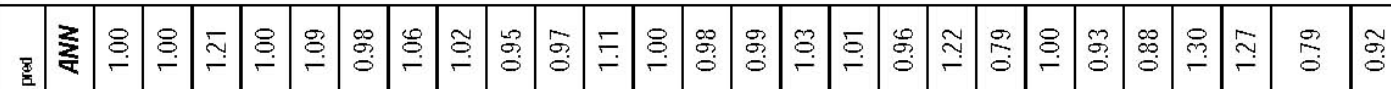

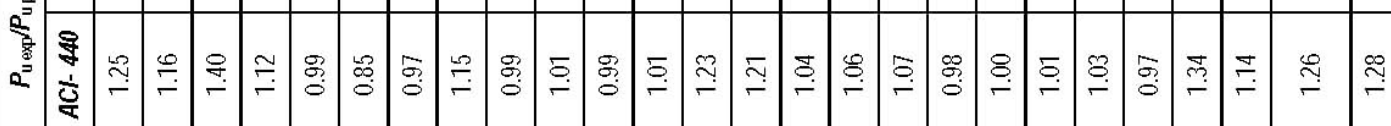

\section{讎}

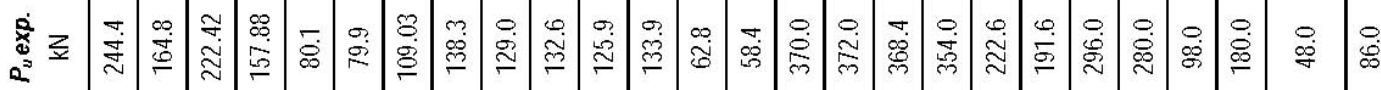

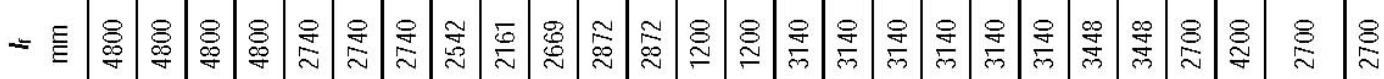

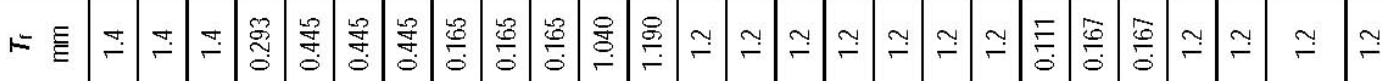

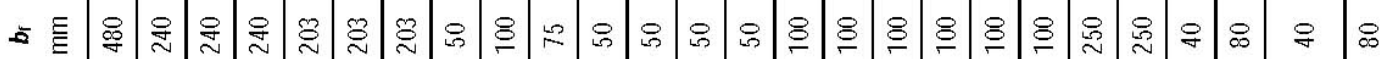

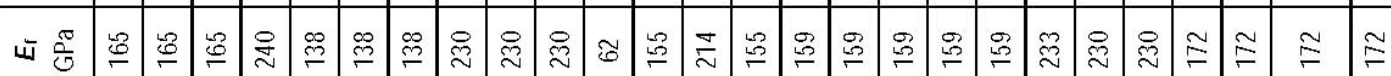

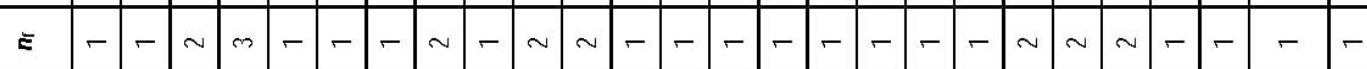

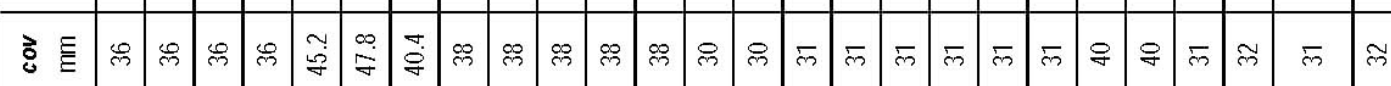

山

舟 总总总

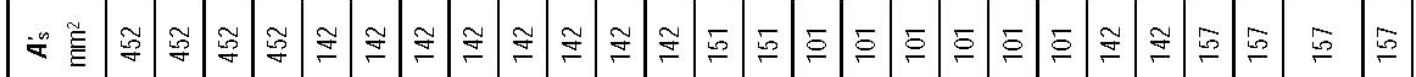

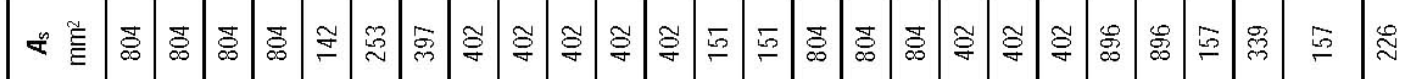

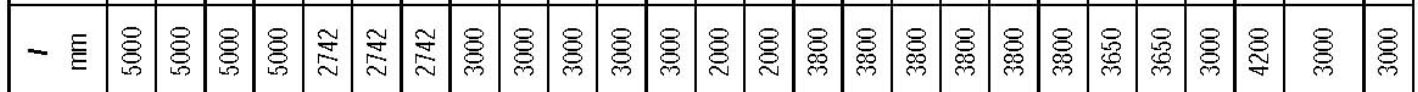

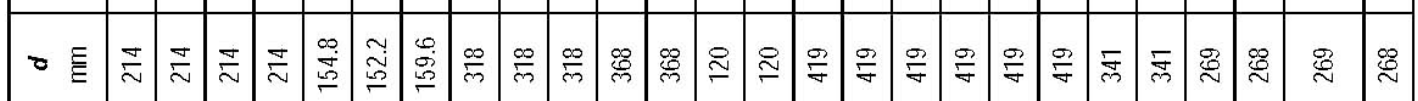

ـ 在

\begin{tabular}{|c|c|c|c|c|c|c|c|c|c|c|c|c|c|c|c|c|c|c|c|c|c|c|c|c|c|}
\hline$\leftarrow \frac{\Gamma}{\Sigma}$ & & & p & קి & $\mid \begin{array}{l}\infty \\
0 \\
6\end{array}$ & $\begin{array}{l}\infty \\
\dot{H}\end{array}$ & $\stackrel{\infty}{\dot{b}}$ & & & & & & & & & & & & g. & ने & & : & 6 & & \\
\hline
\end{tabular}

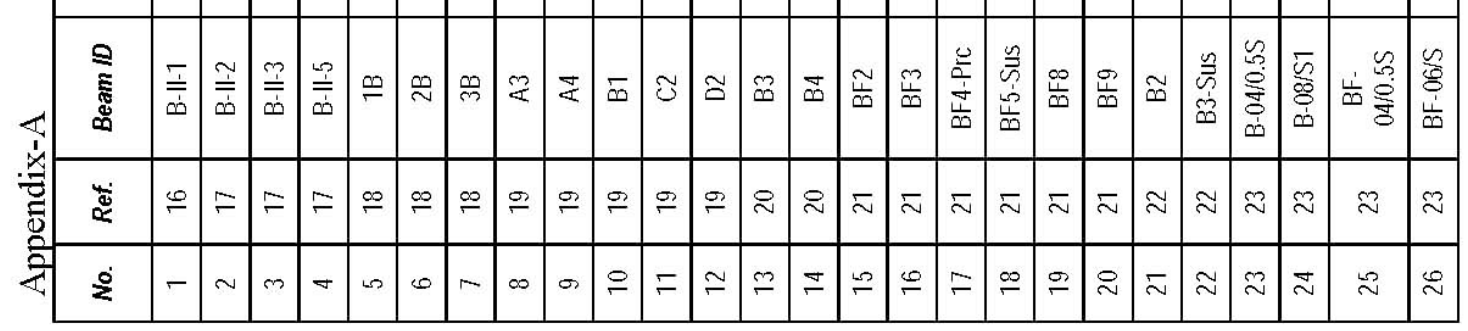




\begin{tabular}{|c|c|c|c|c|c|c|c|c|c|c|c|c|c|c|c|c|c|c|c|c|c|c|c|c|c|}
\hline 离 & 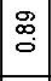 & $\begin{array}{c}\mathscr{0} \\
0 \\
0\end{array}$ & $\stackrel{\text { Oे }}{-}$ & 告 & 晜 & 告 & $\stackrel{m}{\longrightarrow}$ & $\stackrel{\circ}{-}$ & $\stackrel{5}{\rightleftarrows}$ & 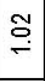 & $\stackrel{8}{\circ}$ & $\stackrel{\circ}{\circ}$ & $\stackrel{\circ}{-}$ & $\stackrel{-}{\circ}$ & $\stackrel{\circ}{-}$ & $\underset{\delta}{\sigma}$ & $\begin{array}{l}\mathscr{D} \\
0 \\
0 \\
0\end{array}$ & $\begin{array}{c}3 \\
0 \\
0\end{array}$ & $\stackrel{m}{=}$ & $\stackrel{\square}{\circ}$ & $\stackrel{m}{\circ}$ & $\stackrel{8}{\circ}$ & $\stackrel{ }{\circ}$ & $\stackrel{m}{\stackrel{\leftrightarrow}{\circ}}$ & $\stackrel{\infty}{\circ}$ \\
\hline 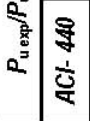 & 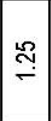 & $\stackrel{\bar{̣}}{\longrightarrow}$ & $\stackrel{\leftrightarrow}{\circ}$ & $\stackrel{\text { 吕 }}{-}$ & 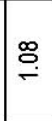 & O্ণ & $\stackrel{8}{\circ}$ & 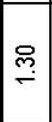 & 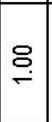 & $\begin{array}{l}\mathscr{8} \\
\stackrel{8}{0}\end{array}$ & 总 & $\bar{\sigma}$ & \begin{tabular}{|l|}
$\mathscr{O}$ \\
\hdashline \\
\hdashline
\end{tabular} & $\begin{array}{l}\infty \\
\stackrel{8}{0} \\
\end{array}$ & $\stackrel{\infty}{\stackrel{\infty}{+}}$ & $\stackrel{\leftrightarrow}{-}$ & \begin{tabular}{|l|}
$\infty$ \\
\hdashline \\
\end{tabular} & $\stackrel{\square}{\square}$ & $\stackrel{ \pm}{\stackrel{\Delta}{\longrightarrow}}$ & $\underset{.}{\mp}$ & $\stackrel{m}{=}$ & $\stackrel{\leftrightarrow}{\circ}$ & $\begin{array}{l}\infty \\
\infty \\
0\end{array}$ & $\stackrel{\Xi}{\stackrel{\Xi}{\circ}}$ & $\stackrel{ }{\circ}$ \\
\hline 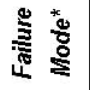 & $N$ & $\sim$ & $N$ & $\sim$ & $\sim$ & $\sim$ & $\sim$ & $\sim$ & $\sim$ & $\sim$ & $\sim$ & $\sim$ & $\sim$ & $\sim$ & $\sim$ & $\sim$ & $\sim$ & $\sim$ & $\sim$ & $\sim$ & $\sim$ & $\sim$ & - & $\nabla$ & $\nabla$ \\
\hline$\underset{a^{2}}{\stackrel{x}{2}}$ & $\stackrel{\circ}{\stackrel{9}{g}}$ & $\stackrel{\circ}{\circ}$ & $\begin{array}{l}\infty \\
\stackrel{\infty}{m} \\
\stackrel{m}{m}\end{array}$ & 㸃 & $\frac{10}{8 g}$ & 竎 & 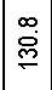 & \begin{tabular}{|l|}
$\stackrel{2}{2}$ \\
$\stackrel{\infty}{\infty}$ \\
$\underset{\sigma}{\infty}$
\end{tabular} & $\begin{array}{l}0.00 \\
\stackrel{10}{*}\end{array}$ & $\underset{\infty}{\stackrel{q}{+}}$ & 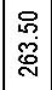 & $\begin{array}{l}\stackrel{P}{0} \\
\text { 品 }\end{array}$ & 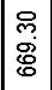 & $\begin{array}{l}q \\
\stackrel{g}{m} \\
\dot{m}\end{array}$ & 怘 & $\mid \begin{array}{l}\tilde{y} \\
\varrho \\
\varrho\end{array}$ & \begin{tabular}{|l|}
$\infty$ \\
$\infty$ \\
$\infty$ \\
$\infty$ \\
$⿱ ㇒$
\end{tabular} & $\begin{array}{l}\stackrel{\infty}{\infty} \\
\stackrel{\infty}{\infty} \\
\end{array}$ & \begin{tabular}{l|}
2 \\
$\stackrel{2}{8}$ \\
8
\end{tabular} & 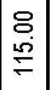 & 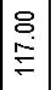 & 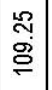 & $\frac{20}{6}$ & $\stackrel{\square}{\stackrel{\circ}{\circ}}$ & $\underset{⿱}{\stackrel{J}{*}}$ \\
\hline$\approx E$ & ণัฒ & 崖 & $\overline{8}$ & $\stackrel{5}{\frac{5}{8}}$ & $\underset{\text { s. }}{\stackrel{5}{8}}$ & $\stackrel{\check{8}}{\stackrel{8}{8}}$ & 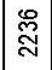 & $\underset{\sim}{\mathbb{N}}$ & 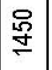 & $\stackrel{8}{\stackrel{8}{+}}$ & 商 & 商 & 亭 & 亭 & 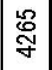 & 兽 & ్ㅗำ & 오ํ & 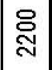 & సั. & స̊ํํ & స̊ํํ & 导 & 呑 & 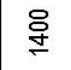 \\
\hline$\stackrel{E}{\xi}$ & $\stackrel{\Upsilon}{=}$ & $\stackrel{\sim}{=}$ & $\stackrel{t}{\leftarrow}$ & $\stackrel{+}{-}$ & $\stackrel{+}{-}$ & $\stackrel{+}{\circ}$ & $\stackrel{5}{\longrightarrow}$ & - & $\stackrel{8}{\circ}$ & $\stackrel{\leftrightarrow}{\circ}$ & $\frac{\Omega}{0}$ & $\frac{2}{80}$ & $\stackrel{8}{\circ}$ & $\frac{5}{0}$ & 0 & $\stackrel{+}{\stackrel{0}{-}}$ & $\bar{\vdots}$ & $\underset{0}{\overline{0}}$ & $\underset{0}{\overline{0}}$ & $\bar{\vdots}$ & $\underset{\vdots}{5}$ & $\underset{0}{\circ}$ & $\stackrel{9}{\stackrel{0}{\circ}}$ & $\stackrel{9}{\stackrel{9}{0}}$ & $\stackrel{9}{\check{0}}$ \\
\hline$\Leftrightarrow$ & స్ & 요 & జ2 & $\overline{i s}$ & $\overline{\text { is }}$ & ऽ & 路 & 용 & $\begin{array}{l}\infty \\
\stackrel{\infty}{0} \\
\stackrel{0}{0}\end{array}$ & \begin{tabular}{|l|}
$\infty$ \\
$\stackrel{0}{0}$ \\
$\stackrel{0}{0}$
\end{tabular} & 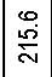 & $\mid \begin{array}{l}0 \\
\stackrel{2}{N} \\
N\end{array}$ & $\begin{array}{l}: \\
: \\
m\end{array}$ & 음 & ๙ూ & $\stackrel{\cong}{\Xi}$ & 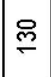 & $\stackrel{\text { p }}{-}$ & 品 & $\stackrel{p}{-}$ & 요 & 욤 & 요 & . & ถి \\
\hline Lั & $\cong$ & $\cong$ & 贶 & 点 & 虾 & 旡 & $\approx$ & 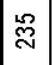 & $\stackrel{\text { m }}{\text { N }}$ & $\stackrel{\mathscr{N}}{\sim}$ & $\stackrel{\sim}{\sim}$ & $\stackrel{\sim}{\sim}$ & $\stackrel{\mathscr{N}}{\tilde{N}}$ & 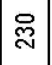 & $\ddot{m}$ & $=$ & $\stackrel{\sim}{\sim}$ & $\stackrel{\sim}{\sim}$ & $\stackrel{\mathscr{N}}{\mathrm{N}}$ & $\stackrel{\sim}{\sim}$ & $\stackrel{\sim}{\sim}$ & $\stackrel{\mathscr{N}}{\mathrm{N}}$ & $\overline{\mathrm{N}}$ & $\tilde{w}$ & $\bar{\sim}$ \\
\hline$=$ & - & - & - & - & - & - & - & - & - & $\sim$ & $\sim$ & + & $m$ & - & - & - & $\sim$ & $\sim$ & $\sim$ & $\sim$ & $\sim$ & $\sim$ & - & $\sim$ & $m$ \\
\hline ठे है & ๙ & న & $\stackrel{2}{2}$ & $\mathbb{N}$ & $\stackrel{2}{2}$ & $\stackrel{2}{2}$ & से & 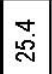 & 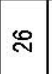 & $\ddot{\sim}$ & ธి & ธ్ర & กิ & $\stackrel{2}{2}$ & 恕 & $\stackrel{2}{N}$ & $\frac{m}{m}$ & $\frac{m}{m}$ & $\frac{m}{m}$ & $\stackrel{m}{m}$ & $\frac{m}{m}$ & $\frac{m}{m}$ & $\mathscr{N}$ & జ & $\mathscr{N}$ \\
\hline 山ూ 융 & $\stackrel{\leftrightarrow}{\circ}$ & $\stackrel{2}{\circ}$ & ్ㅗ & 요 & 오․ & 요 & ్ํ & ్ㅗ & $\stackrel{\varnothing}{\leftarrow}$ & $\stackrel{\varnothing}{\rightleftharpoons}$ & $\stackrel{\mathscr{\infty}}{\stackrel{\infty}{\circ}}$ & $\cong$ & $\underset{\infty}{\infty}$ & 里 & ్ㅗ & 윰 & 을 & ్ㅗ & 오 & 옹 & 오․ & 오 & ్ㅗ & ్ํ & ิㅗ \\
\hline$\Leftrightarrow \frac{\pi}{2}$ & 多 & 守 & ণ্ণী & ঙ্ণ & 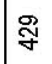 & ฟึ & $\frac{10}{4}$ & $\frac{9}{y}$ & 尔 & 点 & 尃 & 考 & 鳳 & 守 & 曽 & $\frac{m}{q}$ & 奖 & $\stackrel{\mathscr{m}}{\sigma}$ & 壶 & $\stackrel{\mathscr{m}}{\mathscr{\gamma}}$ & 学 & 䑝 & প্ণ & 导 & 字 \\
\hline षं $\tilde{\xi}$ & 5 & 5 & $\stackrel{\tilde{I}}{\tilde{I}}$ & 等 & 畀 & 等 & ₹ & 5 & $\stackrel{5}{=}$ & 5 & $\stackrel{\infty}{0}$ & §ొ & $\stackrel{8}{\circ}$ & $\bar{\sigma}$ & $\stackrel{\circ}{\circ}$ & $\stackrel{\infty}{\sim}$ & ป & ₹ & 守 & I & 荨 & I & $\sqrt[5]{5}$ & is & is \\
\hline षं है है & ఖ్ల & প్లి & ఖ్లి & 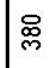 & 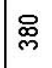 & 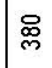 & శ్ & ఫ̃ & $\stackrel{\mathscr{N}}{\sim}$ & 兽 & 急 & 㞼 & $\frac{m}{d}$ & 5 & ळ & $=$ & 岕 & 岕 & 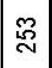 & 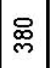 & 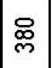 & 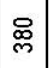 & జి & జ్ & సి \\
\hline$-\underline{E}$ & 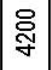 & 号 & 桴 & $\begin{array}{l}\widehat{\tilde{m}} \\
\text { 多 }\end{array}$ & 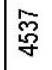 & $\begin{array}{c}\bar{\rho} \\
\text { 多 }\end{array}$ & 孰 & 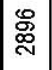 & 용 & 음 & 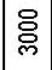 & 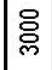 & 灾 & 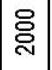 & \begin{tabular}{|l|} 
\\
5 \\
8
\end{tabular} & 일 & 高 & 亳 & 亳 & 亳 & 亳 & 亳 & 응 & 응 & ఫ్రి \\
\hline ○ & $\underset{N}{\infty}$ & $\stackrel{\infty}{\infty}$ & సి & సี & సి & సి & $\stackrel{\sim}{\sim}$ & 忌 & నิ & ลิ & 导 & 导 & 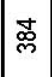 & 용 & 암 & 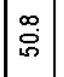 & $\stackrel{\infty}{\infty}$ & 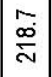 & 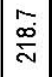 & 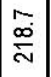 & 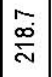 & $\stackrel{\infty}{\infty}$ & $\because$ & $\because$ & $\cong$ \\
\hline$\therefore \frac{E}{E}$ & 요 & 용 & is & స్ & స్ & กี & న్ & స్ & $\stackrel{\mathscr{L}}{=}$ & $\stackrel{\Omega}{=}$ & 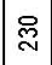 & 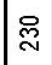 & \begin{tabular}{l}
$\infty$ \\
$:$ \\
\hdashline
\end{tabular} & 음 & 足 & $\widetilde{\Xi}$ & . & $\stackrel{\circ}{\circ}$ & 용 & : & 욤 & 은 & 요 & 요 & 요 \\
\hline * $\frac{\pi}{2}$ & $\underset{m}{m}$ & $\stackrel{m}{\tilde{m}}$ & 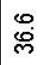 & $\begin{array}{l}\mathscr{8} \\
\ddot{8}\end{array}$ & \begin{tabular}{|l|}
0 \\
$\ddot{m}$
\end{tabular} & @̊ & 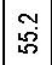 & 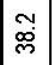 & \begin{tabular}{l}
$\infty$ \\
\multirow{\gamma}{*}{} \\
\end{tabular} & 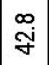 & \begin{tabular}{|l|}
$\infty$ \\
\multirow{j}{*}{}
\end{tabular} & $\begin{array}{l}\infty \\
\text { j } \\
\end{array}$ & \begin{tabular}{|l|}
$\infty$ \\
I \\
\end{tabular} & $\ddot{~}$ & 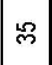 & $\overline{\mathrm{g}}$ & $\stackrel{\infty}{-}$ & $\stackrel{\infty}{-}$ & $\stackrel{\infty}{\leftarrow}$ & $\infty$ & $\infty$ & $\stackrel{\infty}{\leftarrow}$ & ผู้ & ผึ่ & జึี \\
\hline 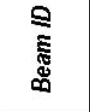 & $\begin{array}{l}\text { \o } \\
\text { ò } \\
\text { ஸे }\end{array}$ & $\begin{array}{l}\tilde{W} \\
\mathscr{O} \\
\text { ஸे } \\
\end{array}$ & $\bar{I}$ & ิㅗ & \begin{tabular}{|l}
$\bar{x}$ \\
조․
\end{tabular} & 포 & 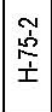 & ๓ & $\underset{\&}{\mathscr{q}}$ & $\&$ & $\mathscr{\infty}$ & 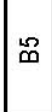 & ठ & $\tilde{\varkappa}$ & $\infty$ & $\bar{\alpha}$ & 㣽 & $\overrightarrow{\mathbb{Z}}$ & 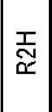 & প్ల & ल) & 佽 & 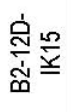 & 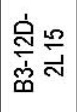 & 完 \\
\hline ¿ & $\mathscr{N}$ & 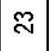 & A & t & I & A & $\stackrel{2}{\sim}$ & $\mathscr{N}$ & $\approx$ & $\approx$ & $\approx$ & $\approx$ & $\tilde{N}$ & $\stackrel{\sim}{\sim}$ & $\mathscr{N}$ & י্ল & $\bar{m}$ & $\bar{m}$ & $\bar{m}$ & $\bar{m}$ & $\bar{m}$ & $\bar{m}$ & న్ల & న్ల & న్ల \\
\hline i & $\approx$ & $\stackrel{\infty}{\sim}$ & : & లి & $\bar{m}$ & $\widetilde{m}$ & m & জ & $\stackrel{m}{m}$ & 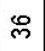 & $\bar{m}$ & 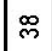 & g্ল & 웅 & $\bar{y}$ & ₹ & $\mathscr{Y}$ & \& & 尔 & $q$ & F & $\stackrel{\infty}{q}$ & g & is & $\bar{s}$ \\
\hline
\end{tabular}




\begin{tabular}{|c|c|c|c|c|c|c|c|c|c|c|c|c|c|c|c|c|c|c|c|c|c|c|c|c|c|c|}
\hline$\stackrel{8}{\circ}$ & $\stackrel{ \pm}{\leftarrow}$ & $\cong$ & $\stackrel{\text { to }}{\longrightarrow}$ & $\stackrel{\leftrightarrow}{\stackrel{\circ}{\circ}}$ & $\stackrel{\infty}{\stackrel{\infty}{\circ}}$ & 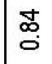 & 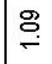 & $\stackrel{\text { to }}{\sigma}$ & $\underset{f}{\stackrel{\sigma}{\sigma}}$ & $\stackrel{\text { og }}{-}$ & $\stackrel{\infty}{\stackrel{\leftrightarrow}{\leftarrow}}$ & 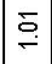 & $\underset{\leftarrow}{-}$ & $\stackrel{\stackrel{\leftrightarrow}{-}}{\circ}$ & $\mid \begin{array}{l}\mathscr{g} \\
0 \\
0\end{array}$ & $\underset{\leftarrow}{-}$ & $\stackrel{\circ}{\leftarrow}$ & 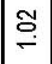 & 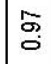 & $\underset{\sigma}{-}$ & \begin{tabular}{|l}
$\stackrel{8}{8}$ \\
0
\end{tabular} & $\begin{array}{l}\approx \\
0 \\
0\end{array}$ & 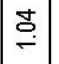 & ণ্ডে & 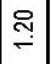 & 㐫 \\
\hline 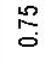 & $\stackrel{\substack{\infty \\
0}}{0}$ & 志 & $\stackrel{0}{\stackrel{0}{0}}$ & 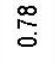 & $\stackrel{\bar{\infty}}{\circ}$ & $\stackrel{\Xi}{\rightleftarrows}$ & f & $\stackrel{\circ}{-}$ & $\stackrel{\infty}{i}$ & مُ & $\stackrel{\mathbb{2}}{=}$ & 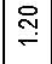 & $\stackrel{\bar{m}}{\leftarrow}$ & $\stackrel{12}{\div}$ & $\stackrel{\square}{\circ}$ & $\stackrel{\text { p্}}{\sim}$ & $\begin{array}{l}\infty \\
\stackrel{\infty}{\infty}\end{array}$ & $\bar{\delta}$ & $\stackrel{5}{\longrightarrow}$ & $\stackrel{\mathbb{Z}}{=}$ & $\stackrel{ \pm}{=}$ & $\stackrel{9}{\check{C}}$ & $\bar{ঙ}$ & $\stackrel{8}{\circ}$ & $\stackrel{\circ}{\circ}$ & $\stackrel{\text { }}{\stackrel{2}{\circ}}$ \\
\hline- & - & - & - & $\sim$ & $m$ & - & - & - & $\theta$ & $\nabla$ & $\nabla$ & - & in & - & $\sim$ & $\sim$ & $\sim$ & in & $\sim$ & + & - & - & 0 & $\infty$ & $\infty$ & $1-$ \\
\hline 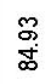 & $\begin{array}{l}\text { Oे } \\
\text { \& }\end{array}$ & $\begin{array}{l}\bar{\delta} \\
\text { ֶू }\end{array}$ & $\begin{array}{l}\text { ల్ } \\
\stackrel{8}{\circ}\end{array}$ & $\begin{array}{l}\bar{\sigma} \\
\infty \\
0 \\
=\end{array}$ & 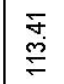 & $\underset{\infty}{\infty}$ & 흐 & 응 & 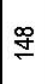 & $\stackrel{\infty}{\circ}$ & 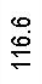 & $\mathscr{\mathscr { C }}$ & $\stackrel{\infty}{\sim}$ & 怘 & $\tilde{\mathrm{d}}$ & 冓 & 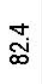 & $\underset{\infty}{\bar{\infty}}$ & $\stackrel{\infty}{\stackrel{\infty}{\circ}}$ & ָั่ & \begin{tabular}{|l|}
$\infty$ \\
$\infty$ \\
$\infty$
\end{tabular} & ָ̃ & 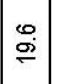 & $\begin{array}{l}\infty \\
\text { జू. }\end{array}$ & $\begin{array}{l}\infty \\
\stackrel{\infty}{\infty} \\
\text { L }\end{array}$ & In: \\
\hline 잉 & Ф્口 & Ф્口 & 응 & 음 & 응 & $\stackrel{8}{?}$ & 옹 & 옹 & 옹 & $\stackrel{8}{\stackrel{ }{ }}$ & 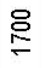 & 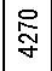 & 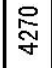 & 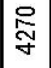 & $\stackrel{\text { O্̊ }}{\circ}$ & 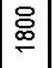 & 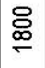 & $\underset{\Phi}{\stackrel{\infty}{\circ}}$ & 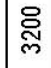 & 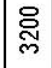 & 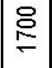 & 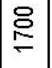 & 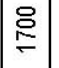 & $\stackrel{ }{\stackrel{8}{ }}$ & 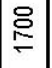 & $\stackrel{ }{\stackrel{\circ}{\circ}}$ \\
\hline$\stackrel{0}{\stackrel{2}{\circ}}$ & $\stackrel{\mathscr{P}}{\stackrel{2}{\circ}}$ & $\stackrel{0}{\stackrel{2}{\circ}}$ & $\stackrel{\mathscr{O}}{\stackrel{2}{\circ}}$ & 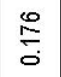 & $\stackrel{0}{\stackrel{2}{\circ}}$ & $\frac{0}{6}$ & $\frac{0}{0}$ & $\frac{\bar{\sigma}}{0}$ & $\stackrel{5}{\circ}$ & $\stackrel{5}{\circ}$ & $\stackrel{5}{\circ}$ & $\stackrel{\Xi}{\leftarrow}$ & $\stackrel{+}{\leftarrow}$ & \begin{tabular}{|l}
$\infty$ \\
\multirow{\sigma}{*}{}
\end{tabular} & $\frac{\Sigma}{5}$ & $\frac{\Sigma}{\vdots}$ & $\underset{\vdots}{E}$ & $\underset{\bar{O}}{\bar{E}}$ & $\stackrel{ナ}{\rightleftarrows}$ & $\stackrel{+}{-}$ & $\stackrel{8}{\circ}$ & $\frac{8}{0}$ & 送 & $\stackrel{8}{\circ}$ & $\frac{8}{0}$ & $\stackrel{8}{\circ}$ \\
\hline 음 & 요 & 요 & 음 & 요 & 足 & ఫ్ & ్ి & ి్ & ఫ్ & ిิ & ి్ & $\stackrel{9}{1}$ & 9 & $\nsubseteq$ & ని & నิ & ণิ & 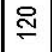 & ถి & 음 & $\stackrel{ }{=}$ & 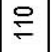 & 음 & 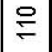 & 을 & $\stackrel{ }{=}$ \\
\hline$\widehat{\tilde{N}}$ & 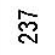 & 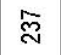 & 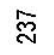 & 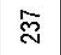 & $\widehat{\widehat{N}}$ & $\ddot{\mathscr{N}}$ & ల్ల & 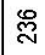 & ஜ্లি & $\mathscr{\mathscr { N }}$ & 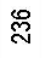 & $\stackrel{\infty}{\stackrel{\infty}{!}}$ & $\stackrel{\infty}{\stackrel{\infty}{!}}$ & 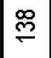 & $\stackrel{\mathscr{్}}{\sim}$ & 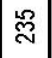 & $\stackrel{\text { }}{\sim}$ & $\stackrel{\text { }}{\sim}$ & $\stackrel{\leftrightarrow}{\stackrel{2}{2}}$ & 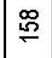 & శ్లి & ஜ్ & 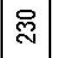 & శ్లి & శ్లి & প్లি \\
\hline- & - & $\sim$ & - & - & $\sim$ & - & - & $\sim$ & $\sim$ & $m$ & $m$ & $\sim$ & $m$ & - & - & $\sim$ & - & $\sim$ & - & $\sim$ & - & $\sim$ & - & - & - & $\sim$ \\
\hline$\stackrel{2}{N}$ & $\stackrel{2}{2}$ & $\stackrel{2}{2}$ & $\stackrel{2}{2}$ & $\stackrel{2}{N}$ & $\stackrel{2}{\sim}$ & $\stackrel{\infty}{\sim}$ & $\stackrel{\infty}{\sim}$ & $\stackrel{\infty}{\sim}$ & $\stackrel{\infty}{\sim}$ & $\stackrel{\infty}{\sim}$ & $\stackrel{\infty}{\infty}$ & \begin{tabular}{|c|c}
10 \\
0 \\
0
\end{tabular} & \begin{tabular}{|c|c}
10 \\
0 \\
0
\end{tabular} & 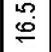 & $\mathscr{N}$ & $\mathscr{2}$ & $\stackrel{2}{2}$ & ผึ & జ్ల & $\stackrel{2}{2}$ & $\stackrel{20}{2}$ & $\stackrel{20}{\leftarrow}$ & $\stackrel{20}{-}$ & $\stackrel{20}{2}$ & $\stackrel{20}{2}$ & in \\
\hline స్ & 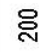 & 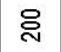 & ్․ & ঐ్ & 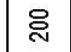 & ్ㅗ & ్ి & స్ & స్ & ి్ & ঐ్ & స్ & ్ి & ్. & స్ & స్ & ్ㅗ & స్ & ి్లి & స్ & సి & ి్ & ి్ & స్ & ిิ & 요 \\
\hline 导 & 亲 & 学 & 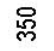 & 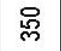 & 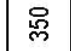 & ষ্లি & ষ্লি & ৪্লি & ষ্লি & $\stackrel{\circ}{\circ}$ & ष्ల & $\frac{8}{4}$ & $\frac{d}{2}$ & $\frac{8}{4}$ & 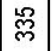 & 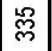 & 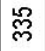 & 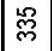 & f & 导 & 总 & 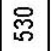 & 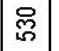 & 惢 & 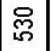 & i̊ \\
\hline$\sqrt[5]{2}$ & $\sqrt[5]{5}$ & $\sqrt[5]{2}$ & $\stackrel{50}{2}$ & $\sqrt[5]{5}$ & $\sqrt{5}$ & 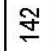 & 等 & $\stackrel{\mathcal{F}}{\mathcal{Y}}$ & Fै & \& & ₹ & $\stackrel{\Im}{\Im}$ & 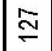 & 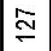 & 5 & 5 & $\sqrt[50]{2}$ & in & $\stackrel{\mathbb{N}}{ }$ & స్ & $\stackrel{\infty}{\infty}$ & $\infty_{\infty}^{\infty}$ & 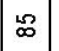 & $\stackrel{\text { m }}{\circ}$ & 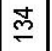 & $\stackrel{\text { m }}{\circ}$ \\
\hline ণ̃ & ণ̃ & ণ̃ & ర్రి & జ్రి & ర్రి & 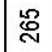 & 恣 & $\stackrel{2}{2}$ & 怘 & 㣽 & $\stackrel{\overbrace{}}{N}$ & ळ్ & ळ్ & ळొ & జి & జ్ & 守 & 守 & $\stackrel{\mathbb{N}}{ }$ & సి & $\infty$ & $\infty$ & 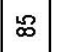 & $\stackrel{\text { m }}{-}$ & $\stackrel{m}{m}$ & $\stackrel{m}{m}$ \\
\hline 응 & 응 & 응 & 응 & $\stackrel{\circ}{\circ}$ & 음 & 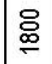 & 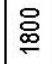 & 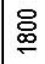 & 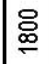 & 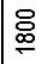 & 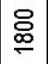 & $\begin{array}{l}0 \\
\stackrel{2}{6} \\
\dot{5}\end{array}$ & $\begin{array}{l}2 \\
\stackrel{2}{5} \\
\text { s }\end{array}$ & \begin{tabular}{|l}
0 \\
15 \\
8
\end{tabular} & 怘 & 怘 & ర్సి & ণ্ডి & 命 & 守 & 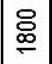 & $\underset{\infty}{\stackrel{\infty}{\circ}}$ & $\underset{\stackrel{\Phi}{\mathbf{~}}}{\sim}$ & 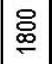 & 高 & $\underset{\text { 南 }}{-}$ \\
\hline$\stackrel{ \pm}{ \pm}$ & $\underset{0}{ \pm}$ & $\underset{\Xi}{\Xi}$ & Ð & ঠ్ & § & $\stackrel{8}{0}$ & 哭 & 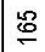 & $\stackrel{\text { \& }}{0}$ & $\stackrel{8}{\circ}$ & 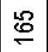 & 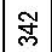 & 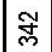 & 今్ & $\bar{\sim}$ & $\bar{\sim}$ & 오 & 오 & 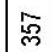 & 点 & $\stackrel{\infty}{\infty}$ & $\mathscr{\infty}$ & $\stackrel{\infty}{\infty}$ & $\stackrel{\infty}{\infty}$ & 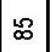 & 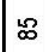 \\
\hline ณి & 요 & ని & ถి & .ొ & 욤 & ั్ & ్․ & ి् & ః్ & ిิ & ్ి & ల్లి & ల్ల & প্লি & ని & 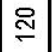 & 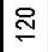 & $\stackrel{乛}{\sim}$ & ి్సి & 오․ & 号 & 욤 & 盟 & 号 & 욤 & 㖞 \\
\hline$\stackrel{\infty}{\tilde{N}}$ & $\stackrel{\infty}{\underset{N}{ }}$ & $\stackrel{\infty}{\underset{\sim}{ }}$ & $\overline{\mathrm{d}}$ & $\overline{\mathrm{I}}$ & $\overline{\mathrm{I}}$ & ભ్లి & $\stackrel{m}{m}$ & m & 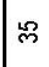 & 点 & 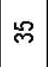 & $\bar{m}$ & $\bar{m}$ & $\bar{m}$ & $\underset{\infty}{\infty}$ & \begin{tabular}{|l}
\multirow{\infty}{\infty}{} \\
$\stackrel{0}{\sigma}$
\end{tabular} & $\underset{\varpi}{\stackrel{\varpi}{\varpi}}$ & \begin{tabular}{l}
\multirow{\infty}{\infty}{} \\
$\stackrel{\infty}{*}$
\end{tabular} & $\stackrel{m}{m}$ & m & $\stackrel{N}{*}$ & $\mathscr{N}$ & Dis & N & $\mathscr{N}$ & I্ \\
\hline 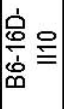 & 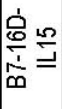 & & 㸗을 & 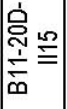 & 旁 & $\begin{array}{l}\overline{0} \\
\text { ô }\end{array}$ & 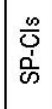 & $\begin{array}{l}\tilde{D} \\
\text { ஸे }\end{array}$ & $\begin{array}{l}\text { ป̃ँ } \\
\text { ஸे }\end{array}$ & $\begin{array}{l}3 \\
\dot{1} \\
\text { के }\end{array}$ & $\begin{array}{l}\stackrel{心}{0} \\
\stackrel{1}{\infty} \\
\infty\end{array}$ & 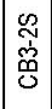 & 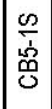 & \begin{tabular}{|l|} 
\\
$\frac{1}{1}$ \\
0 \\
0
\end{tabular} & 운 & జ్తి & $\frac{0}{\infty}$ & ષ్లి & 产 & $\begin{array}{l}\text { Oे } \\
\text { ஸे }\end{array}$ & $\approx$ & $\dddot{4}$ & \& & ๓ు & $\check{\varnothing}$ & Ф \\
\hline 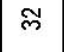 & ๗ & న్ల & ๗్ల & న్ల & ल & ল্ল & ল্ল & ল্ল & ল্ল & ల্লি & ల্ল & 焉 & 声 & 商 & 足 & $\stackrel{\mathscr{m}}{.}$ & 萠 & $\stackrel{m}{m}$ & 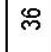 & $\mathscr{m}$ & $\hat{m}$ & $\tilde{m}$ & $\bar{m}$ & 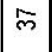 & $\hat{m}$ & m \\
\hline ஸี & ณ & is & 员 & is & is & in & is & 8 & $\bar{\sigma}$ & $\widetilde{\Xi}$ & 8 & ष & 恕 & 8 & $\check{0}$ & 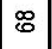 & 8 & P & $\Sigma$ & $\approx$ & $m$ & I & $\stackrel{2}{2}$ & $\stackrel{9}{2}$ & $F$ & $\stackrel{\infty}{\sim}$ \\
\hline
\end{tabular}




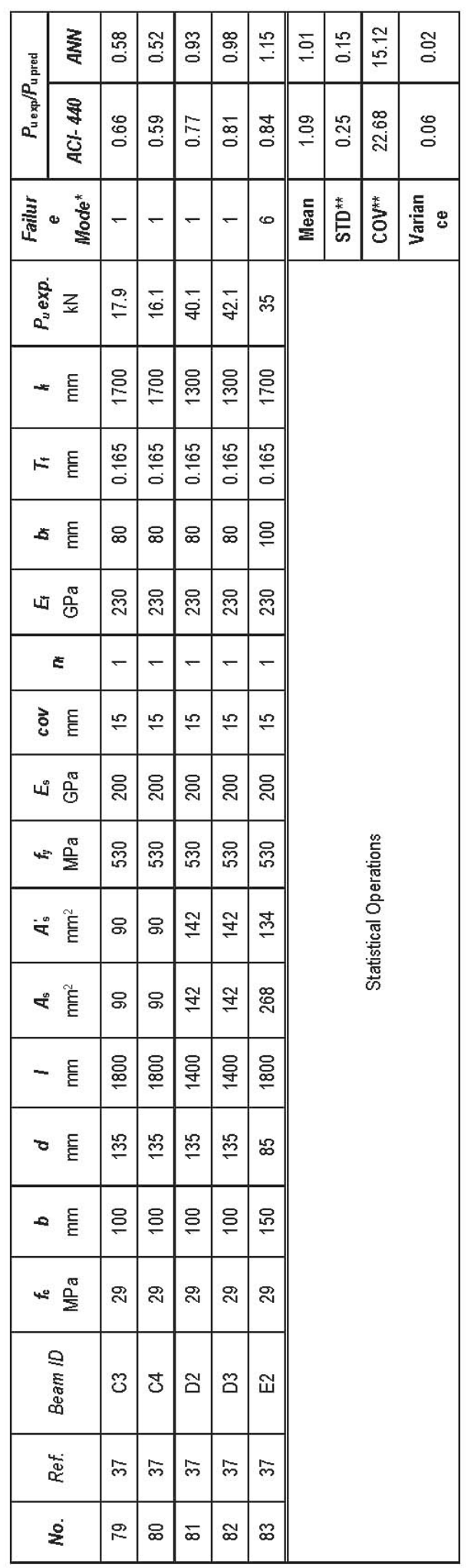

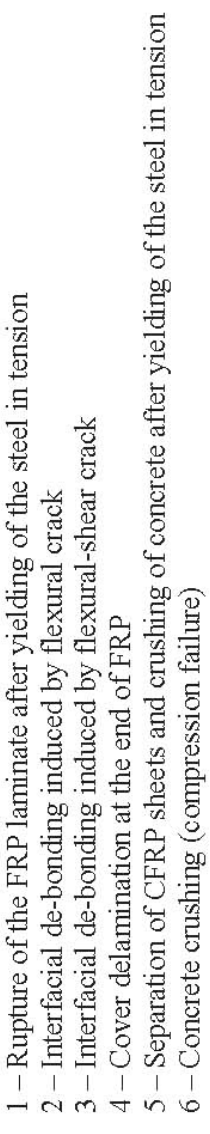

